\title{
Bending Creep Properties of Cross-Laminated Wood Panels Made with Tropical Hardwood and Domestic Temperate Wood $^{1}$
}

\author{
Han-Min PARK $\mathbb{D}^{2, \dagger} \cdot$ Do-Min $\mathrm{GONG}^{2} \cdot$ Moon-Gi $\mathrm{SHIN}^{2} \cdot$ Hee-Seop BYEON ${ }^{2}$
}

\begin{abstract}
For efficient use and expansion of domestic small- and medium-diameter woods, cross-laminated wood panels composed of tropical hardwoods and domestic temperate woods were fabricated, and the bending creep behavior under long-term loading was investigated. The bending creep curve of the cross-laminated wood panels showed an exponential function graph with a sharp increase at the top right side. The wood panel composed of a teak top layer and larch core and bottom layers recorded the highest initial deformation, and that composed of a merbau top layer and tulip core and bottom layers showed the lowest initial deformation. Creep deformation of the cross-laminated wood panels showed the highest value in that composed of a teak top layer and larch core and bottom layers and showed the lowest value in that composed of a merbau top layer and tulip core and bottom layers. The obtained creep deformation is 3.1-4.3 times that of merbau, however, it is remarkably lower than that of tulip and larch. The highest relative creep was recorded by the wood panel composed of merbau top layer and larch core and bottom layers, whereas that composed of the teak top layer and tulip core and bottom layers showed the lowest relative creep.
\end{abstract}

Keywords: wood species, bending creep, initial deformation, creep deformation, relative creep

\section{INTRODUCTION}

Tropical hardwoods, represented by south pacific hardwoods, have been widely used as plywood veneers and decks in Korea. It is recently used as top layer plate for hardwood floors. Tropical hardwoods are expected to exhibit relatively high strength performance and durability when it is used in combination with domestic temperate woods because of their hardness and good durability. It is especially expected to contribute to the efficient use and expansion of do- mestic temperate woods when the top layer lamina which requires high strength and durability uses tropical hardwoods such as currently available wooden floorboards and the lower layer supporting members of the core and bottom layer laminae where plywood have been mainly used are replaced by small and medium diameter domestic temperate woods. When wood and wood-based materials are used as building materials, it is very important to understand the creep performance because they are subjected to a continuous load over a long period of time.

${ }^{1}$ Date Received May 15, 2020, Date Accepted July 23, 2020

2 Division of Environmental Forest Science, Institute of Agriculture \& Life Science, Gyeongsang National University, Jinju, 52828, Republic of Korea.

$\dagger$ Corresponding of author: Han-Min PARK (e-mail: phm0691@gnu.ac.kr, ORCID: 0000-0001-6322-5985) 
Wood is a viscoelastic material that has both viscosity and elasticity as is well known, and the deformation after loading is gradually increased, and after removal of the load, the deformation is not completely recovered and remains a part of permanent deformation. This is a disadvantage in that wood and woodbased materials are used as building materials. Although there have been various studies on the physical and mechanical properties of cross-laminated wood panels (Gülzow et al., 2011; Ido et al., 2014; Oh et al., 2017; Pang et al., 2017; Jang \& Lee, 2019; Galih et al., 2020), there are few studies on creep properties. Most of the studies on the bending creep property of cross-laminated wood panels have been conducted with cross-laminated wood panels made with Japanese cedar (Park et al., 2002) and various temperate woods (Park et al., 2005; Byeon et al., 2017). In the previous report (Byeon et al., 2018), for the purpose of expanding the use of domestic temperate wood and efficient use, two species of tropical woods in south pacific and two species of domestic temperate woods were combined to make cross-laminated wood panels, and static bending test was performed to evaluate bending strength performance. As a result, the bending modulus of elasticity (MOE) of the cross-laminated wood panels made with tropical woods and domestic temperate woods was higher in cross-laminated wood panels with the merbau longitudinal direction lamina in the face than in that with teak longitudinal direction lamina in the face, and the bending modulus of rupture (MOR) had the higher value in the cross-laminated wood panels with tulip perpendicualr and longitudinal direction laminae in the core and bottom than in that with larch perpendicular and longitudinal direction laminae in the core and bottom, regardless of face materials. It was found that this value was $1.4-2.5$ times higher than that of flooring boards specified in Korean industrial standard (KS, 2016, 2017).

In this study, in order to investigate the deformation characteristics of long-term loads of cross-laminated wood panels cross-laminating tropical hardwoods in south pacific and domestic temperate woods, crosslaminated wood panels which mix two species of tropical hardwoods and two species of domestic temperate woods were manufactured, and the creep behavior under long-term load was investigated by bending creep test.

\section{MATERIALS and METHODS}

\subsection{Specimen preparation}

Two tropical hardwoods in south pacific and two domestic temperate woods were selected for this study. They were merbau(Intsia bijuga), teak(Tectona grandis), Japanese larch(Larix kaempferi) and tulip (Liriodendron tulipifera L.). The fabrication process of the test specimens was the same as that of the bending test of the previous study (Byeon et. al., 2018). The elements of $80 \mathrm{~mm}(\mathrm{~W}) \times 7 \mathrm{~mm}(\mathrm{H}) \times 720 \mathrm{~mm}(\mathrm{~L})$ size were made from the sawn woods of four wood species, and were used as longitudinal-direction laminae. The nine sawn woods of Japanese larch and tulip of $80 \mathrm{~mm}(\mathrm{~W}) \times 7 \mathrm{~mm}(\mathrm{H}) \times 720 \mathrm{~mm}(\mathrm{~L})$ were widthwise-jointed and the square widthwise-jointed plates were manufactured. And they were cut to the $80 \mathrm{~mm}$ width and were used as perpendicular-direction laminae.

Cross-laminated wood panels were consisted of teak and merbau longitudinal-direction laminae in the top layer, Japanese larch and tulip perpendicular-direction laminae in the core layer and Japanese larch and tulip longitudinal-direction laminae in the bottom layer. And the densities of each laminae were measured, and were cured with aqueous polymeric isocyanate resin (MPU-500, Okong Co., Ltd. 15 parts of curing agent was added to 100 parts of the adhesive base). The adhesive was spreaded on both side with the amount of $300 \mathrm{~g} / \mathrm{m}^{2}$, and the compression force of $0.34 \mathrm{MPa}$ was applied using a torque wrench, and 
the compression was performed for 24 hours. After the compression, the specimens were maintained for more than 2 weeks in a constant temperature and humidity room of $20^{\circ} \mathrm{C}, 65 \% \mathrm{RH}$, and the excess adhesive was removed and cut into $20 \mathrm{~mm}(\mathrm{~W}) \times 21 \mathrm{~mm}(\mathrm{H})$ $\times 350 \mathrm{~mm}(\mathrm{~L})$ size as shown in Fig. 1. These materials were used as the specimens. The symbols used for the test specimens are teak (T), merbau (M), Japanese larch (La), and tulip (Tu). Therefore each laminated wood panels were named as follows; teak-larch crosslaminated wood panels (TLa), teak-tulip cross-laminated wood panels (TTu), merbau-larch cross-laminated wood panels (MLa), and merbau-tulip cross- laminated wood panels (MTu). As described above, four types of the cross-laminated wood panels were subjected to bending creep test so that each type could be tested four times.

\subsection{Bending creep test}

Bending creep test for cross-laminated wood specimens was conducted by four-point loading as shown in Fig. 2. The span was $300 \mathrm{~mm}$, and the distance between a loading point and a supporting point was 100 $\mathrm{mm}$. The stress corresponding to $25 \%$ of breaking stress obtained from static bending test was applied to each specimen. The applied stresses are shown in Fig. 2.

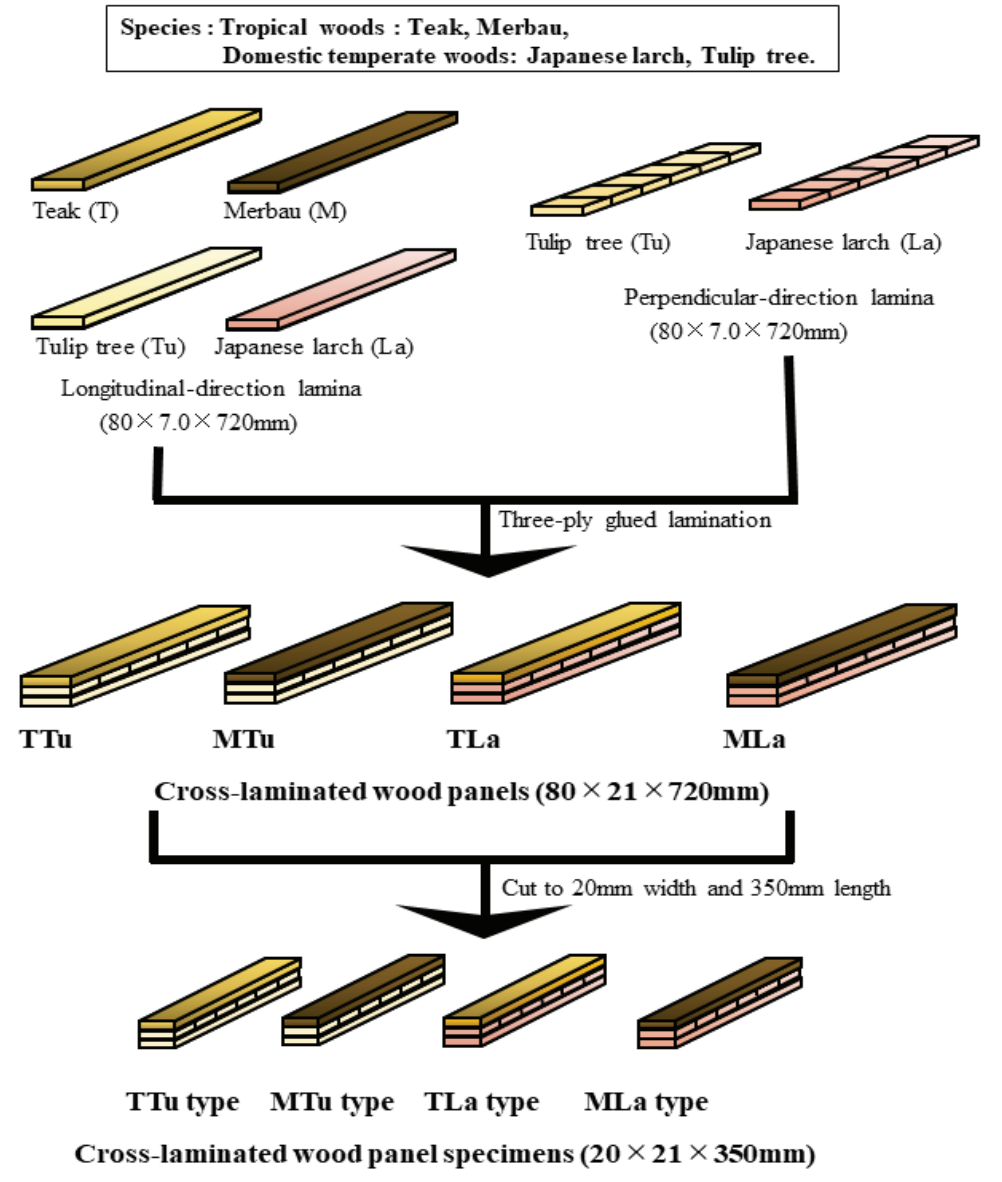

Fig. 1. Laminated wood specimens and their preparation. 


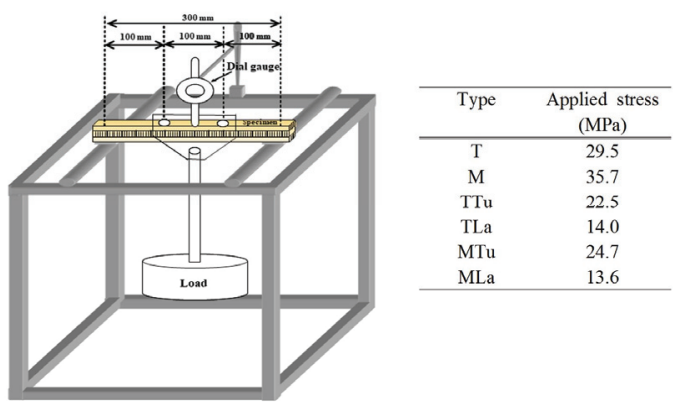

Fig. 2. Schematic diagram and applied stresses of bending creep test. T: Teak, M: Merbau, TTu: Teaktulip cross-laminated wood panel, TLa: Teak-larch cross-laminated wood panel, MTu: Merbau-tulip cross-laminated wood panel. MLa: Merbau-larch cross-laminated wood panel.

The creep test was conducted for $168 \mathrm{hr}$ (7 days) in a constant atmosphere maintained at $20^{\circ} \mathrm{C}$ and $65 \%$ RH. The deflection of the mid-span was measured with a dial gauge. Total creep compliance $D(t)$ and creep compliance $D_{\mathrm{c}}(t)$ (total creep compliance except for initial compliance) were obtained using Eqs (1) and (2) as follows:

$$
D(t)=4 b h^{3} y(\mathrm{t}) / P a\left(3 l^{2}-4 a^{2}\right)
$$

where $P$ : Applied load $(\mathrm{N})$

$l:$ Span $(\mathrm{mm})$

$b:$ Width of the beam $(\mathrm{mm})$

$h$ : Depth of the beam $(\mathrm{mm})$

$a$ : Distance between a loading point and a supporting point $(\mathrm{mm})$

$y(t)$ : Apparent deflection at time $(t)$ between both supporting points and contains the deflection $(\mathrm{mm})$

$D(t)$ : Apparent total creep compliance obtained from the apparent deflection containing the deflection caused by shear force $\left(\mathrm{Pa}^{-1}\right)$.

$$
D_{\mathrm{c}}(t)=D(t)-D(0.008)
$$

where $D(0.008)$ : Total creep compliance at $t=0.008 \mathrm{~h}(30 \mathrm{~s})$ and called initial compliance $\left(\mathrm{Pa}^{-1}\right)$.

\section{RESULTS and DISCUSSION}

\subsection{Bending creep curves of laminated woods}

Typical examples of the bending creep curves of the cross-laminated wood panels made by cross-laminating tropical woods and domestic temperate woods are shown in Fig. 3.

For two tropical woods, the bending creep curve showed a form of an exponential function plot with an increase in the upper right side, although there was a slight difference in each increase. It was found that the extent of the increase was higher in teak than in merbau. The bending creep curves of cross-laminated wood panels made with tropical woods and domestic temperate woods were also shown to be an exponential function plot in which the upper right side was sharply increased regardless of the cross-laminated type.

Fig. 4 shows the double logarithm plots of creep compliances and time for each type of cross-laminated

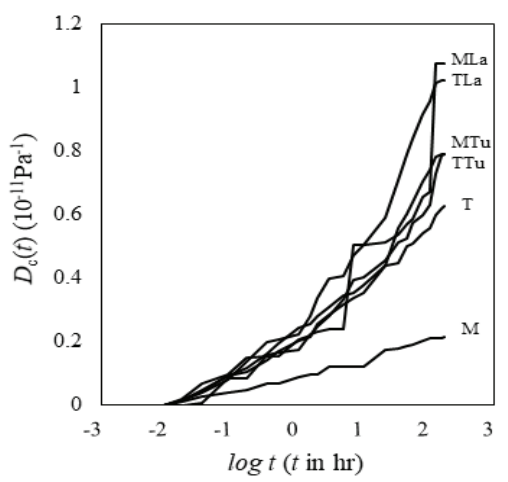

Fig. 3. Typical examples of creep curves for crosslaminated wood specimens made by hybrid lamination of tropical woods in south pacific and domestic temperate woods. T: Teak, M: Merbau, TTu: Teaktulip cross-laminated wood panel, TLa: Teak-larch cross-laminated wood panel, MTu: Merbau-tulip crosslaminated wood panel, MLa: Merbau-larch crosslaminated wood panel. 


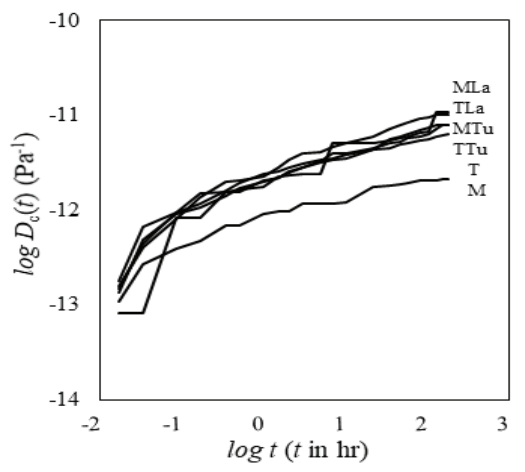

Fig. 4. Double logarithm plots of creep deformation and time for typical examples of cross-laminated wood panels made by hybrid lamination of tropical woods in south pacific and domestic temperate woods. T, M, TTu, TLa, MTu, MLa: See the note in Fig. 3.

wood panels. In general, the creep curves of wood and wood-based materials fit into the power law expressed by Eq. (3) (Schniewind, 1968; Saito et al., 1980; Arima et al., 1981; Morizumi, 1981; Hoyle et al., 1994; Aratake et al., 2002).

$$
D_{\mathrm{c}}(t)=A t^{N}
$$

where, $A$ and $N$ : Constants

$$
t: \text { Time (hr) }
$$

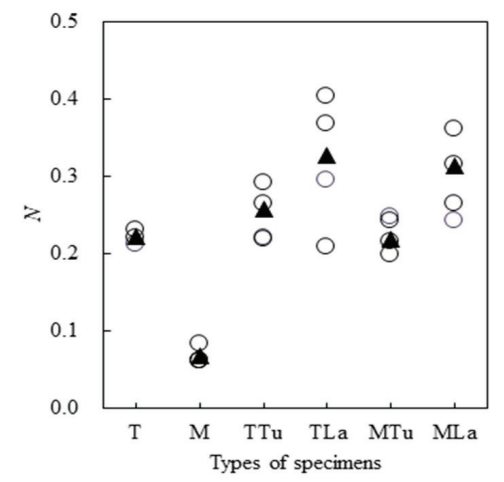

For two tropical woods and most of cross-laminated wood panels made with tropical woods and domestic temperate woods, creep curves showed curvilinear behavior for up to 1 hour after initial deformation, but then showed almost linear behavior for up to 168 hours. However, for the MLa type with cross-laminating merbau and larch, all four measurement specimens showed a stepwise increase in creep deformation.

Using the least-squares method, the creep curves $D_{\mathrm{c}}(t)$ from 1 hour to 168 hour were fitted to $A t^{N}$, and obtained $N$ and $A$ values. The $N$ and $A$ values are shown in Table 1 and Fig. 5. In the logarithm regression of Eq. (3), the correlation coefficients were in the range of $0.976-0.997$ in the tropical woods and in the range of $0.909-0.991$ in cross-laminated wood panels. $N$ value was 0.221 on average in teak, but was very low value of 0.068 on average in merbau, and it was confirmed that the difference was about 3.2 times between two tropical woods.

The $N$ value of cross-laminated wood panels made with tropical woods and domestic temperate woods had the highest value of 0.326 in TLa type that was composed of teak and larch, and had the lowest value of 0.218 in MTu type that was composed of merbau and

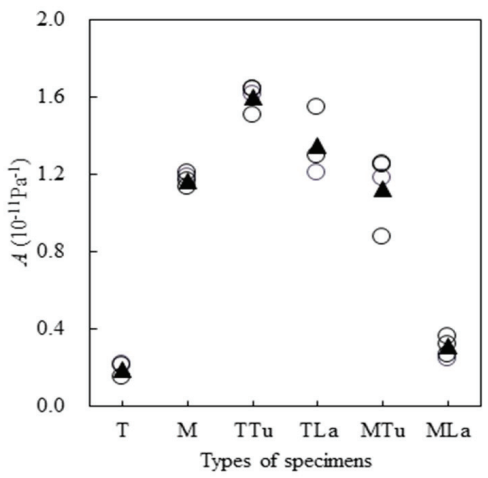

Fig. 5. $N$ and $A$ values of cross-laminated wood specimens made by hybrid lamination of tropical woods in south pacific and domestic temperate woods. $N$ and $A$ are the constant values in the exponential regression between creep compliance and time $\left[D_{\mathrm{c}}(t)=A t^{N}\right] . \mathrm{T}, \mathrm{M}, \mathrm{TTu}, \mathrm{TLa}, \mathrm{MTu}, \mathrm{MLa}$ : See the note in Fig. 3. 
Bending Creep Properties of Cross-Laminated Wood Panels Made with Tropical Hardwood and Domestic Temperate Wood

Table 1. Results of bending creep test of cross-laminated wood specimens made with tropical woods in south pacific and domestic temperate woods

\begin{tabular}{|c|c|c|c|c|c|c|c|}
\hline Type & No & $\begin{array}{c}\rho \\
\left(\mathrm{Mg} / \mathrm{m}^{3}\right)\end{array}$ & $N$ & $\begin{array}{c}A \\
\left(10^{-11} \mathrm{~Pa}^{-1}\right) \\
\end{array}$ & $\begin{array}{r}D(0.008) \\
\left(10^{-11} \mathrm{~Pa}^{-1}\right) \\
\end{array}$ & $\begin{array}{c}D(168) \\
\left(10^{-11} \mathrm{~Pa}^{-1}\right)\end{array}$ & $\begin{array}{c}\text { Relative creep } \\
(\%)\end{array}$ \\
\hline \multirow{5}{*}{$\mathrm{T}$} & 1 & 0.701 & 0.212 & 0.215 & 8.15 & 0.624 & 7.7 \\
\hline & 2 & 0.755 & 0.230 & 0.147 & 6.94 & 0.468 & 6.7 \\
\hline & 3 & 0.683 & 0.220 & 0.211 & 8.61 & 0.631 & 7.3 \\
\hline & AVE & 0.713 & 0.221 & 0.191 & 7.90 & 0.574 & 7.2 \\
\hline & $\mathrm{CV}(\%)$ & 4.3 & 3.3 & 16.2 & 8.9 & 13.1 & 5.2 \\
\hline \multirow{6}{*}{ M } & 1 & 0.779 & 0.060 & 1.183 & 4.49 & 0.223 & 5.0 \\
\hline & 2 & 0.771 & 0.060 & 1.208 & 4.70 & 0.213 & 4.5 \\
\hline & 3 & 0.805 & 0.061 & 1.127 & 4.53 & 0.191 & 4.2 \\
\hline & 4 & 0.817 & 0.082 & 1.161 & 5.13 & 0.260 & 5.1 \\
\hline & AVE & 0.798 & 0.068 & 1.165 & 4.79 & 0.221 & 4.6 \\
\hline & CV $(\%)$ & 2.3 & 13.9 & 2.6 & 5.3 & 11.3 & 7.5 \\
\hline \multirow{6}{*}{ TTu } & 1 & 0.581 & 0.219 & 1.614 & 9.81 & 0.753 & 7.7 \\
\hline & 2 & 0.585 & 0.218 & 1.641 & 9.30 & 0.719 & 7.7 \\
\hline & 3 & 0.571 & 0.264 & 1.506 & 9.84 & 0.787 & 8.0 \\
\hline & 4 & 0.564 & 0.291 & 1.637 & 10.71 & 0.921 & 8.6 \\
\hline & AVE & 0.573 & 0.258 & 1.594 & 9.95 & 0.809 & 8.1 \\
\hline & $\mathrm{CV}(\%)$ & 1.4 & 12.0 & 3.5 & 5.1 & 9.5 & 4.5 \\
\hline \multirow{6}{*}{ TLa } & 1 & 0.578 & 0.294 & 1.206 & 11.25 & 0.828 & 7.4 \\
\hline & 2 & 0.617 & 0.208 & 5.861 & 9.81 & 0.576 & 5.9 \\
\hline & 3 & 0.595 & 0.367 & 1.543 & 10.67 & 1.020 & 9.6 \\
\hline & 4 & 0.558 & 0.402 & 1.295 & 12.27 & 1.102 & 9.0 \\
\hline & AVE & 0.590 & 0.326 & 2.900 & 10.92 & 0.899 & 8.1 \\
\hline & $\mathrm{CV}(\%)$ & 3.7 & 22.8 & 67.5 & 8.2 & 22.5 & 17.7 \\
\hline \multirow{6}{*}{ MTu } & 1 & 0.600 & 0.247 & 1.464 & 7.90 & 0.789 & 10.0 \\
\hline & 2 & 0.612 & 0.241 & 1.447 & 7.96 & 0.829 & 10.4 \\
\hline & 3 & 0.643 & 0.215 & 1.229 & 8.00 & 0.616 & 7.7 \\
\hline & 4 & 0.652 & 0.197 & 1.407 & 7.88 & 0.632 & 8.0 \\
\hline & AVE & 0.636 & 0.218 & 1.361 & 7.95 & 0.692 & 8.7 \\
\hline & CV(\%) & 3.4 & 9.3 & 6.9 & 0.6 & 13.5 & 13.6 \\
\hline \multirow{6}{*}{ MLa } & 1 & 0.665 & 0.241 & 1.177 & 7.62 & 0.734 & 9.6 \\
\hline & 2 & 0.660 & 0.264 & 1.244 & 8.29 & 1.153 & 13.9 \\
\hline & 3 & 0.627 & 0.360 & 1.252 & 9.00 & 1.074 & 11.9 \\
\hline & 4 & 0.623 & 0.315 & 0.870 & 7.84 & 0.604 & 7.7 \\
\hline & AVE & 0.637 & 0.313 & 1.122 & 8.38 & 0.944 & 11.2 \\
\hline & CV(\%) & 3.0 & 14.7 & 13.9 & 6.3 & 24.2 & 20.9 \\
\hline
\end{tabular}

Notes; $\rho$ : Density, $N$ and $A$ are the constant values in the exponential regression between creep compliance and time $\left[D_{\mathrm{c}}(t)\right.$

$\left.=A t^{N}\right], D(0.008)$ is initial compliance (at $\left.0.008 \mathrm{~h}\right), D_{\mathrm{c}}(168)$ is creep compliance except for initial compliance at $168 \mathrm{~h}(D(168)$

- $D(0.008)), R_{\mathrm{c}}$ is relative creep $\left(100\left(D_{\mathrm{c}}(168) / D(0.008)\right)\right.$, T: Teak, M: Merbau, TTu: Teak-tulip cross-laminated wood panel, TLa: Teak-larch cross-laminated wood panel, MTu: Merbau-tulip cross-laminated wood panel, MLa: Merbau-larch cross-laminated wood panel. 
tulip. The values were in order of TLa $>$ MLa $>$ TTu $>$ MTu. In general, the $N$ value of the cross-laminated wood panels was decreased due to the low $N$ value of tropical woods. It was found that the extent of the decrease was greater in TTu and MTu types cross-laminating tropical woods and tulip than in the TLa and MLa types cross-laminating tropical woods and larch. It was found that the $N$ value of cross-laminated wood panels made with tropical and domestic temperate woods was 1.0 - 1.5 times higher than that of teak, and 3.2 - 4.8 times higher than that of merbau. These values were in the similar range to $N=0.240-0.377$ in cross-laminated wood panels parallel to the grain in the face of the previous study (Park et al., 2002, 2006) and $N=0.245-0.340$ in the wood-aluminum hybrid composite materials of previous study (Park et al., 2007). And it was somewhat lower than $N=0.300$ - 0.378 of glulam under constant humidity or humidity change (Hoyle et al., 1994; Aratake \& Arima, 1995; Aratake et al., 2002).

In addition, for the cross-laminated wood panels cross-laminating tropical woods and tulip, the $N$ values were almost similar to those of wood-based boards such as plywood and particle board (Nakai, 1978; Arima, 1981) and wood and wood-based board com- posites under constant humidity (Park et al., 2010). And the values were slightly higher than those of the cross-laminated wood panels cross-laminating tropical woods and larch.

The $A$ values of cross-laminated wood panels made with tropical woods and domestic temperate woods were tended to increase with increasing the amount of creep deformation. The values showed the lower values in the cross-laminated wood panels cross-laminating merbau and domestic temperate woods than in that cross-laminating teak and domestic temperate woods.

\subsection{Initial deformation and creep deformation}

Initial deformation and creep deformation of tropical woods and cross-laminated wood panels are shown in Table 1 and Fig. 6. The initial deformation of tropical woods was about 1.6 times higher value in teak than in merbau, and creep deformation was about 2.6 times higher in teak than in merbau. The initial deformation of cross-laminated wood panels showed the highest value in TLa type composed of teak and larch. The values were in order of TLa $>$ $\mathrm{TTu}>\mathrm{MLa}>\mathrm{MTu}$, and cross-laminated wood panels
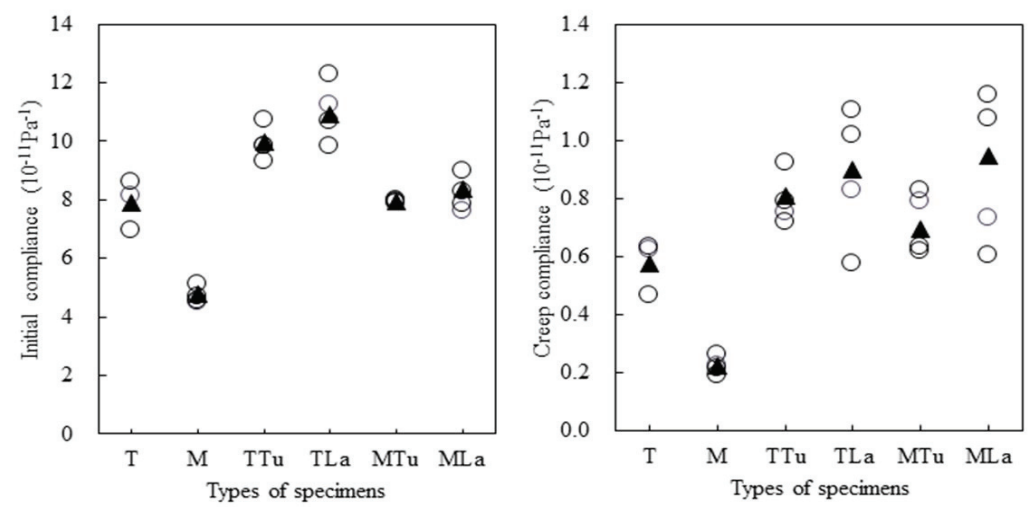

Fig. 6. Initial and creep compliances of cross-laminated wood specimens made by hybrid lamination of tropical woods in south pacific and domestic temperate woods. T, M, TTu, TLa, MTu, MLa: See the note in Fig. 3. 
composed of merbau in face had the lower initial deformation than that composed of teak in face. This value showed 1.0-1.4 times higher values than that of teak, and 1.7-2.3 times higher than that of merbau. On the other hand, creep deformation showed the highest value in MLa type, and the lowest value in MTu type. The values were in order of MLa $>$ TLa $>$ TTu $>$ MTu. Unlike the initial deformation, the MLa type showed the highest value due to the variation of the specimens by cutting the large-sized sectioning material for floorboard into small specimens, and as shown in Table 1, it can be seen that the coefficient of variation between specimens is considerably larger than other types. This value was 1.2-1.6 times higher than that of teak and 3.1-4.3 times higher than that of merbau. In general, it was confirmed that creep deformation was larger than the initial deformation in comparison with tropical woods. This value was 0.1-0.2 times compared to the creep deformation parallel to the grain of the face of cross-laminated woods made with Japanese cedar (Park et al., 2002, 2005), and it was 0.2-0.4 times lower than the creep deformation parallel to the grain of the face of cross-laminated woods made with royal paulownia, Japanese cedar, Japanese cypress, katsura and beech (Park et al., 2006). Also, this value showed 0.8-3.5 times higher than creep deformation of Japanese cedar-aluminum hybrid laminated composite (Park et al., 2007). And it was 0.5-0.8 times lower than creep deformation of wood-concrete hybrid composite (Park et al., 2015), and was 0.3-0.8 times lower than creep deformation parallel to the grain of the face of cross-laminated woods made with six temperate woods (Park et al., 2017).

\subsection{Relative creep of cross-laminated wood panels}

Relative creep as represented as the percentage of creep compliance at $168 \mathrm{hr}$ to initial compliance of tropical woods and cross-laminated wood panels made with tropical woods and domestic temperate woods is shown in Table 1. The relative creep of tropical woods was $7.2 \%$ and $4.6 \%$ for teak and merbau respectively. The relative creep of cross-laminated wood panels showed the highest value of $11.2 \%$ in MLa type and the lowest value of $8.1 \%$ in TTu type. The values were in order of MLa $>$ MTu $>$ TLa $>$ TTu. This value was 1.1-1.7 times higher than that of teak, and was 1.8-2.4 times higher than that of merbau. This value was 0.4-0.5 times lower than relative creep parallel to the grain to the face of cross-laminated wood panels made with Japanese cedar (Park et al., 2002), and was 0.7-1.0 times lower than that of wood-concrete laminated composite (Cho et al., 2015). Also, it was 0.7-0.9 times lower than the relative creep parallel to the grain of the face of cross-laminated wood panels made with six temperate woods (Byeon et al., 2017).

\section{CONCLUSION}

In this study, cross-laminate wood panels were manufactured from tropical woods and domestic temperate woods and bending creep behavior was investigated, and the following results were obtained.

1) Bending creep curves of cross-laminated wood panels made with tropical woods and domestic temperate woods showed exponential form. It showed curvilinear behavior until one hour and then linear behavior until 168 hour and it was possible to predict deformation under long-term load by fitting the power law.

2) Initial deformation of cross-laminated wood panels showed the highest value in teak-larch crosslaminated wood panel (TLa) and the lowest value in merbau-tulip cross-laminated wood panel (MTu) with high density and strength performance. The values were $1.7-2.3$ times higher deformation than that of merbau. 
3) Creep deformation of cross-laminated wood panels showed the highest value in merbau-larch cross-laminated wood panel (MLa) and the lowest value in merbau-tulip cross-laminated wood panel (MTu). The values were $3.1-4.3$ times higher deformation than that of merbau, however it was considerably lower deformation than that of larch.

4) Relative creep of cross-laminated wood panels showed the highest value in merbau-larch crosslaminated wood panel (MLa) and the lowest value in teak-tulip cross-laminated wood panel (TTu). The values were $1.1-1.7$ times higher than that of teak and $1.8-2.4$ times lower than that of merbau.

\section{REFERENCES}

Aratake, S., Arima, T. 1995. Creep of sugi sawn lumber in process of humidity changes (in Japanese). Mokuzai Gakkaishi 41(4): 359-366.

Aratake, S., Morita, H., Arima, T. 2002. Creep of various structural members in ambient conditions I. Estimation of future deflections considering the longevity of wooden structures (in Japanese). Mokuzai Gakkaishi 48(4): 233-240.

Arima, T., Sato, M., Mashita, K. 1981. Studies on evaluation method for long-term performance of wood-based materials and elements (in Japanese). Report of the Building Research Institute 95: 25-80. Byeon, J.W., Kim, T.H., Yang, J.K., Byeon, H.S., Park, H.M. 2017. Bending creep property of crosslaminated woods made with six domestic species. Journal of the Korean Wood Science and Technology 45(6): 689-702.

Byeon, J.W., Kim, T.H., Yang, J.K., Byeon, H.S., Park, H.M. 2018. Static bending performances of crosslaminated wood panels made with tropical and temperate woods. Journal of the Korean Wood
Science and Technology 46(6): 726-734.

Cho Y.J., Byeon, J.W., Lee, J.R., Sung, E.J. Park, H.M. 2015. Bending creep performance of domestic wood-concrete hybrid laminated materials. Journal of the Korean Wood Science and Technology 44(1): 57-66.

Gülzow, A., Richter, K., Stelger, R. 2011. Influence of wood moisture content on bending and shear stiffness of cross-laminated timber panels. Eur J Wood Prod 69(2): 193-197.

Hoyle, R.J., Itani, R.Y., Anderson, J.T. 1994. The effect of moisture cycling on creep of small glued laminated beams. Wood Fiber Science 26(4): 556-562.

Ido, H., Nagao, H., Miura, S., Miyatake, A. 2014. Compressive strength properties perpendicular to the grain of cross-laminated timber (CLT) composed of sugi laminations. Mokuzai Gakkaishi 60(1): 16-22. In Japanese with summary in English.

Jang, S.S., Lee, H.W. 2019. Lateral resistance of CLT wall panels composed of square timber larch core and plywood cross bands. Journal of the Korean Wood Science and Technology 47(5): 547-556.

Korean Industrial Standards (KS F 3111). 2016. Natural wood veneer flooring board. Korean Industrial Standards (KS F 3126). 2017. Decorative wood-based flooring board.

Moriizumi, S. 1981, Creep properties of wood-based boards under plate shear test (in Japanese). Journal of the Hokkaido Forest Products Research Institute 359: 6-14.

Nakai, T. 1978. Bending creep test on wood-based boards I (in Japanese). Wood Insustry, 33(4): 158-160.

Galih, N.M., Yang, S.M., Yu, S.M., Kang, S.G. 2020. Study on the mechanical properties of tropical hybrid cross laminated timber using bamboo laminated board as core layer. Journal of the Korean Wood Science and Technology 48(2): 245-252. Oh, J.K., Kim, G.C., Kim, K.M., Lee, J.J., Hong, J.P. 
Bending Creep Properties of Cross-Laminated Wood Panels Made with Tropical Hardwood and Domestic Temperate Wood

2017. End distance of single-shear screw connection in cross laminated timber. Journal of the Korean Wood Science and Technology 45(6): 746-752. Park, H.M., Fushitani, M., 2007. Bending creep property of wood -aluminum hybrid laminated material (in Japanese). Mokuzai Gakkaishi 53(1): 14-24

Park, H.M., Fushitani, M., Kubo, T., Sato, K., Byeon, H.S. 2002. Bending creep performance of crosslaminated sugi wood. Mokuzai Gakkaishi 48(3): 166-177. In Japanese with summary in English. Park, H.M., Fushitani, M., Sato, K., Kubo, T., Byeon, H.S. 2006. Bending creep performances of three-ply cross-laminated woods made with five species.
Journal of Wood Science 52(3): 220-229.

Park, H.M., Kang, D.H., Choi, Y.E., Ahn, S.Y., Ryu, H.S., Byeon, H.S. 2010. Bending creep performances of hybrid laminated woods composed of wood-wood based boards. Journal of the Korean Wood Science and Technology 38(1): 1-10.

Saito, F., Ikeda, M., Ogawa, K. 1980. Time-related flexural behavior of particleboards under long term load (in Japanese). Mokuzai Gakkaishi 26(11): 714-718.

Schniewind, A.P. 1968. Recent progress in the study of the rheology of wood. Wood Science Technology 2(3): 188-206. 